\title{
The Problems of Paddy Cultivators in Erode District: A Case Study
}

\author{
V. Natchimuthu' and R. Umamaheswari ${ }^{2 *}$ \\ 'Associate Professor, Department of Economics, Sri Vasavi College, Erode, \\ India; nachimuthu_2006@yahoo.co.in \\ 2Ph.D., Scholar, Department of Economics, Sri Vasavi College, Erode, \\ India; umaamuthan@yahoo.com
}

\begin{abstract}
Agriculture as a sector has been playing a decisive role in shaping the overall growth trajectories of the Indian economy since independence. Paddy is an important crop cultivated in Erode District, an area having no sea coast of its own. Unfortunately the productivity for the year 2014 was not accompanied by enhanced fertility due to price fluctuations. As a result it has adversely affected the farmers and their production. In this back drop, the present study was undertaken to bring-out the demographic profile of the sample respondents, and to analyse the constraints faced by the paddy cultivators in the selected areas. Primary data was collected by means of a well designed questionnaire. This research used convenience sampling method for collecting the data. 650 sample respondents engaged in paddy cultivation were selected from various taluks of Erode district. Statistical tools like ANOVA (Analysis of Variance) and Henry Garrett Ranking Techniques were used in this research. The study has revealed that the mean level of the annual income remains same for all the three age groups of the paddy cultivators. It is found that majority of the male respondents have earned maximum level of annual income (205.7 thousands) than the female respondents in the study area. Majority of the respondents have felt that price fluctuation and lack of storage facilities were the top most problems in paddy cultivation and the availability of high resistance varieties and supply of fertilizers by government at subsidized price are the most felt future expected practices.
\end{abstract}

Keywords: Annual Income, Farmers' Problems, Paddy Cultivators, Subsistence and Commercial Farmers

\section{Introduction}

Agriculture, as a sector has been playing a decisive role in shaping the overall growth trajectories of the Indian economy since independence. As is well-known, in the overall Gross Domestic Product (GDP) of the country, the contribution of the primary sector (which comprises agriculture, forestry and fishing, mining and quarrying) has come down substantially over the years and it was $13.7 \%$ in 2012-13 ${ }^{1}$. During 1950-51, the primary sector contributed $51.9 \%$ of the country's GDP (at factor cost and at 2004-05 constant prices), which declined to $29.5 \%$ by $1990-91$ and has shrunk further to $13.7 \%$ by $2012-2013^{1}$. Further the share of agriculture alone was a recorded low of $11.6 \%$ in
2012-13, from a much higher share of 41.8 of the GDP $\%$ during 1950-51 [1]. Much of this decline in percentage share of agriculture sector in the overall GDP of the economy seems to have been due to the increasing contributions of other sectors, viz., industry and services sectors during the said period. Such a trajectory of economic transformation as witnessed in India, has been commonly observed across the world. However, in spite of this decline in its share in the country's GDP, half of India's population is still dependent on agriculture as the major source of their livelihood. Moreover as a source of raw-materials for a number of sectors and its share in the country's total exports, the linkage of agriculture with overall economic growth and well-being is well established.

${ }^{*}$ Author for correspondence 


\section{Review of Literature}

According to Radha Raman Singh and Srivastava [2] lack of organized marketing system is responsible for rural poverty and it adversely affects both the subsistence farmer and the commercial farmer and hampers the prospects of agriculture. The researcher suggested that the government action must improve the marketing system for agricultural sector and the government should take efforts on supply of subsidized sale of inputs, provision of cheap or free social amenities in rural areas, establishment of co-operative stores at every central place with branches in every village with facilities to purchase agricultural products at reasonable prices and supply of market information.

Sundaresan and Dhanasekaran [3] in their study on production and marketing of grapes, identified severity of diseases and pest attack, lack of adequate capital facilities to meet the initial establishment costs and high cost of inputs as the major production problems, while unorganized market structure, high marketing costs and unnecessary deductions and lack of finance facilities as important marketing problems.

Salik Ram [4] indicated the problems, prospects and agricultural development in India. According to him, the production of food grains became so low due to drought that more quantities of food grains were required for domestic consumption which ultimately forced India to import from foreign countries. Inflationary rise of agricultural inputs made farming uneconomical. The seed, water, fertilizer technology makes agriculture costly. Only big farmers are benefited by the new technology. Adequate and timely availability of input is quite defective. Heavy wastage in capacity leads to an increase in the cost of production. The support prices and the subsidies granted cannot cope with the high cost. Land reform measures have not been effective in ensuring equality.

Siju and Kombairaju [5] studied the trend in area, production and productivity of rice in Tamil Nadu. They also examined the contribution of area and productivity to total production of rice. They found that the green revolution has significantly contributed to the increase in production of rice in Tamil Nadu.

Suresh [6] focused on crisis in agricultural sector in Tamilnadu. It is asserted that, agriculture in Tamilnadu is undergoing a structural change leading to a crisis situation. The rate of growth of agriculture output was gradually declining in 2011. It is alarming that India is moving towards a point of no return, from being a self-reliant nation of food surplus to a net importer of food. All these trends indicate that the agricultural sector in Tamilnadu is facing a crisis today. The crisis in agriculture is a crisis of the country as a whole. The solution to the problem is not in a few "Packages" but in drastic changes in agriculture.

\section{Objectives of the Study}

- To bring-out the demographic profile of the sample respondents.

- To analyse the constraints faced by the paddy cultivators in the selected areas.

\section{Methodology}

Primary data was collected by means of a well designed questionnaire. This research used convenience sampling method for collecting the data. 650 sample respondents engaged in paddy cultivators were selected from various taluks of Erode district.

\section{Tools of Analysis}

Statistical tools like ANOVA (Analysis of Variance) and Henry Garrett Ranking Techniques were used in this research.

\section{Results and Discussion}

\subsection{Age and Level of Annual Income of the Farmers}

With a view to find the degree of association between age of the respondents and their level of annual income, a twoway table was prepared as shown in Table 1 .

It could be observed from Table 1 that the percentage of high level of annual income was the highest (60.9\%) among farmers aged below 40 years and the same was the lowest (55.6\%) among farmers aged above 50 years. The percentage of medium level of annual income was the highest (19.4\%) among farmers aged above 50 years and the same was the lowest (15.5\%) among farmers aged below 40 years. On the other hand, the percentage of low level of annual income was the highest $(25.0 \%)$ among farmers aged above 50 years and the same was the lowest (23.6\%) among farmers aged below 40 years. Further, it is found that majority of the farmers who belong to above 50 years age category have earned maximum level of annual income (225.8 thousand) than the other paddy cultivators in the study area.

In order to find the relationship between the age of the respondents and level of annual income, a hypothesis was 
Table 1. Age and level of annual income (Two-way table)

\begin{tabular}{|c|c|c|c|c|c|c|c|}
\hline \multirow[t]{2}{*}{ S. No. } & \multirow[t]{2}{*}{ Age } & \multicolumn{3}{|c|}{ Level of Annual Income } & \multirow[t]{2}{*}{ Total } & \multirow{2}{*}{$\begin{array}{c}\text { Mean } \\
\text { (Rs. in } \\
\text { Thousands) }\end{array}$} & \multirow[t]{2}{*}{ S.D } \\
\hline & & $\begin{array}{c}\text { Low } \\
\text { (Rs.50000) }\end{array}$ & $\begin{array}{c}\text { Medium } \\
\text { (Rs.50001-1 } \\
\text { lakh) }\end{array}$ & $\begin{array}{c}\text { High } \\
\text { (Above Rs.1 } \\
\text { lakh) }\end{array}$ & & & \\
\hline 1. & Below 40 years & $\begin{array}{c}41 \\
(23.6 \%)\end{array}$ & $\begin{array}{c}27 \\
(15.5 \%)\end{array}$ & $\begin{array}{c}106 \\
(60.9 \%)\end{array}$ & 174 & 199.0 & 313.2 \\
\hline 2. & 40 - 50 years & $\begin{array}{c}60 \\
(24.6 \%)\end{array}$ & $\begin{array}{c}41 \\
(16.8 \%)\end{array}$ & $\begin{array}{c}143 \\
(58.6 \%)\end{array}$ & 244 & 187.7 & 348.6 \\
\hline 3. & Above 50 years & $\begin{array}{c}58 \\
(25.0 \%)\end{array}$ & $\begin{array}{c}45 \\
(19.4 \%)\end{array}$ & $\begin{array}{c}129 \\
(55.6 \%)\end{array}$ & 232 & 225.8 & 346.5 \\
\hline & Total & 159 & 113 & 378 & 650 & & \\
\hline
\end{tabular}

Source: Computed from primary data

Table 2. Age and level of annual income (ANOVA)

\begin{tabular}{lccccc}
\hline Source & SS & DF & MS & F & Sig. \\
\hline Between Groups & 179501.33 & 2 & 89750.66 & 0.782 & Not Significant \\
Within Groups & 74228314.43 & 647 & 114726.91 & & \\
Total & 74407815.76 & 649 & & & \\
\hline
\end{tabular}

framed and analysed with the help of ANOVA test. The results of the ANOVA test are shown in Table 2.

$\mathrm{H}_{0}$ : The mean level of the annual income remains same for all the three age groups of the paddy cultivators.

$\mathrm{H}_{1}$ : The mean level of the annual income is not same for all the three age groups of the paddy cultivators.

It is observed from the Table 2 that the calculated ' $F$ ' value is lesser than the table value and the result is not significant. So, the null hypothesis is accepted. From the analysis, it is stated that the mean level of the annual income remains same for all the three age group of the paddy cultivators.

\subsection{Gender and Level of Annual Income (Two-Way Table)}

With a view to find the degree of association between gender of the farmers and their level of annual income, a two-way table was prepared as shown in Table 3.

It could be inferred from Table 3 that the percentage of high level of annual income was the highest (65.6\%) among female respondents and the same was the lowest (57.0\%) among male respondents. The percentage of medium level of annual income was the highest (17.7\%) among male respondents and the same was the lowest (15.6\%) among female respondents. On the other hand, the percentage of low level of annual income was the highest (25.4\%) among male respondents and the same was the lowest (18.9\%) among female respondents. Further, it is found that majority of the male respondents have earned maximum level of annual income (205.7 thousands) than the female respondents in the study area.

In order to find the relationship between the gender of the farmers and level of annual income, a hypothesis was framed and analysed with the help of ANOVA test. The results of the ANOVA test are shown in Table 4.

$\mathrm{H}_{0}$ : The mean level of the annual income remains same for all the paddy cultivators with regard to male and female.

$\mathrm{H}_{1}$ : The mean level of the annual income is not same for all the paddy cultivators in regard to male and female.

It is divulged from Table 4 that the calculated ' $\mathrm{F}$ ' value is lesser than the table value and the result is not significant. So, the null hypothesis is accepted. From the analysis, it is stated that the mean level of the annual income remains same for both the gender of the farmers.

\subsection{Education and Level of Annual Income}

With a view to find the degree of association between education of the farmers and their level of annual income, a two-way table was prepared as shown in Table 5.

It can be noted from Table 5 that the percentage of high level of annual income was the highest (69.9\%) among the farmers educated up to HSC and the same was the 
Table 3. Gender and level of annual income (Two-way table)

\begin{tabular}{|c|c|c|c|c|c|c|c|}
\hline \multirow[t]{2}{*}{ S. No. } & \multirow[t]{2}{*}{ Gender } & \multicolumn{3}{|c|}{ Level of Annual Income } & \multirow[t]{2}{*}{ Total } & \multirow{2}{*}{$\begin{array}{c}\text { Mean } \\
\text { (Rs. in Thousands) }\end{array}$} & \multirow[t]{2}{*}{ SD } \\
\hline & & Low & Medium & High & & & \\
\hline 1. & Male & $\begin{array}{c}142 \\
(25.4 \%)\end{array}$ & $\begin{array}{c}99 \\
(17.7 \%)\end{array}$ & $\begin{array}{c}319 \\
(57.0 \%)\end{array}$ & 560 & 205.7 & 352.2 \\
\hline \multirow[t]{2}{*}{2.} & Female & $\begin{array}{c}17 \\
(18.9 \%)\end{array}$ & $\begin{array}{c}14 \\
(15.6 \%)\end{array}$ & $\begin{array}{c}59 \\
(65.6 \%)\end{array}$ & 90 & 195.7 & 238.6 \\
\hline & Total & 159 & 113 & 378 & 650 & & \\
\hline
\end{tabular}

Table 4. Gender and level of annual income (ANOVA)

\begin{tabular}{lccccc}
\hline Source & SS & DF & MS & F & Sig. \\
\hline Between Groups & 7775.353 & 1 & 7775.353 & 0.068 & Not Significant \\
Within Groups & 74400040.414 & 648 & 114814.877 & & \\
Total & 74407815.767 & 649 & & & \\
\hline
\end{tabular}

Table 5. Education and level of annual income (Two-way table)

\begin{tabular}{|c|c|c|c|c|c|c|c|}
\hline \multirow[t]{2}{*}{ S. No. } & \multirow[t]{2}{*}{ Education } & \multicolumn{3}{|c|}{ Level of Annual Income } & \multirow[t]{2}{*}{ Total } & \multirow{2}{*}{$\begin{array}{c}\text { Mean } \\
\text { (Rs. in Thousands) }\end{array}$} & \multirow[t]{2}{*}{ SD } \\
\hline & & Low & Medium & High & & & \\
\hline 1. & Illiterate & $\begin{array}{c}34 \\
(26.4 \%)\end{array}$ & $\begin{array}{c}31 \\
(24.0 \%)\end{array}$ & $\begin{array}{c}64 \\
(49.6 \%)\end{array}$ & 129 & 188.0 & 250.6 \\
\hline 2. & Primary & $\begin{array}{c}64 \\
(28.2 \%)\end{array}$ & $\begin{array}{c}43 \\
(18.9 \%)\end{array}$ & $\begin{array}{c}120 \\
(52.9 \%)\end{array}$ & 227 & 169.6 & 260.7 \\
\hline 3. & SSLC & $\begin{array}{c}23 \\
(21.3 \%)\end{array}$ & $\begin{array}{c}16 \\
(14.8 \%)\end{array}$ & $\begin{array}{c}69 \\
(63.9 \%)\end{array}$ & 108 & 273.8 & 567.4 \\
\hline 4. & HSC & $\begin{array}{c}17 \\
(20.5 \%)\end{array}$ & $\begin{array}{c}8 \\
(9.6 \%)\end{array}$ & $\begin{array}{c}58 \\
(69.9 \%)\end{array}$ & 83 & 232.3 & 315.9 \\
\hline 5. & Graduate & $\begin{array}{c}21 \\
(20.4 \%)\end{array}$ & $\begin{array}{c}15 \\
(14.6 \%)\end{array}$ & $\begin{array}{c}67 \\
(65.0 \%)\end{array}$ & 103 & 206.1 & 271.0 \\
\hline & Total & 159 & 113 & 378 & 650 & & \\
\hline
\end{tabular}

Source: Computed from primary data

Table 6. Education and level of annual income (ANOVA)

\begin{tabular}{lccccc}
\hline Source & SS & DF & MS & F & Sig. \\
\hline Between Groups & 894334.418 & 4 & 223583.604 & 1.962 & Not Significant \\
Within Groups & 73513481.349 & 645 & 113974.390 & & \\
Total & 74407815.767 & 649 & & & \\
\hline
\end{tabular}

lowest (49.6\%) among illiterate farmers. The percentage of medium level of annual income was the highest (24.0\%) among illiterate farmers and the same was the lowest (9.6\%) among the farmers educated up to HSC. On the other hand, the percentage of low level of annual income was the highest (28.2\%) among the famers educated up to primary level and the same was the lowest (20.4\%) among the farmers who are qualified graduates. Further, it is found that the majority of SSLC educated paddy cultivators have earned maximum level of annual income (273.8 thousands) than the other educated respondents in the study area.
In order to find the relationship between the education of the respondents and level of annual income, a hypothesis was framed and analysed with the help of ANOVA test. The results of the ANOVA test are shown in Table 6.

$\mathrm{H}_{0}$ : The mean level of the annual income remains same for all the five categories of the education of the respondents.

$\mathrm{H}_{1}$ : The mean level of the annual income is not same for all the five categories of the education of the respondents. 
It is inferred from Table 6 that the calculated ' $F$ ' value is lesser than the table value and the result is not significant. So, the null hypothesis is accepted. From the analysis, it is stated that the mean level of the annual income remains same for all the five categories of farmers.

\subsection{Problems Faced by Farmers during Marketing of Paddy}

An attempt has been made to know the problems faced during marketing of paddy of the respondents. For the purpose of this study, it has been classified into six categories viz., price fluctuation, heavy commission, lack of storage facilities, and weight loss during transit, lack of awareness on export and price discrimination. To identify the most important problems, Henry Garrett Ranking Technique was employed and the details of ranking the problems faced during marketing of paddy are shown in Table 7.

It can be perceived from Table 7 that of the problems faced during marketing of paddy, the major problem was price fluctuation which ranked first with the Garrett score of 35678 points. It is followed by the second and third ranks assigned to lack of storage facilities and price discrimination with the Garrett scores of 35351 and 32971 points respectively. The fourth and fifth ranks were assigned to heavy commission and weight loss during transit with the Garrett scores of 32147 and 30542 points respectively. The last rank was assigned to lack of awareness in exporting with the Garrett score of 28423 points. It is found from the analysis that the respondents were opined that price fluctuation and lack of storage facilities were the major problems.

\subsection{Future Expected Practices in Paddy Marketing}

An attempt has been made to know the future expected practices in paddy marketing of the respondents. For the purpose of this study, it has been classified into six categories viz., high resistance varieties, improving market potential, direct procurement by government, and government subsidy at higher rate, supply of quality seeds by government and supply of fertilizers by government at subsidized price. To identify the most important factors, Henry Garrett Ranking Technique was employed and the details of ranking the future expected practices in paddy marketing are shown in Table 8.

It is inferred from Table 8 that of the future expected marketing practices in paddy the high resistance varieties got ranked first with the Garrett score of 36024 points. It followed by the second and third ranks assigned to supply of fertilizers by government at subsidized price and supply of quality seeds by government with the Garrett scores of 34816 and 32314 points respectively. The fourth and fifth ranks were assigned to improving market potential and

\begin{tabular}{|c|c|c|c|c|}
\hline No. & Problems & $\begin{array}{l}\text { Total } \\
\text { Score }\end{array}$ & $\begin{array}{l}\text { Mean } \\
\text { Score }\end{array}$ & Rank \\
\hline 1. & Price fluctuation & 35678 & 54.9 & I \\
\hline 2. & Heavy commission & 32147 & 49.5 & IV \\
\hline 3. & Lack of storage facilities & 35351 & 54.4 & II \\
\hline 4. & Weight loss during transit & 30542 & 47.0 & $\mathrm{~V}$ \\
\hline 5. & Lack of awareness in exporting & 28423 & 43.7 & VI \\
\hline 6. & Price discrimination & 32971 & 50.7 & III \\
\hline
\end{tabular}

Table 8. Future expected practices in paddy marketing

\begin{tabular}{llccc}
\hline No. & Factors & $\begin{array}{c}\text { Total } \\
\text { Score }\end{array}$ & $\begin{array}{c}\text { Mean } \\
\text { Score }\end{array}$ & Rank \\
\hline 1. & High resistance varieties & 36024 & 55.4 & I \\
2. & Improving market potential & 31718 & 48.8 & IV \\
3. & Direct procurement by Govt. & 29009 & 44.6 & VI \\
4. & Govt. subsidy at higher rate & 30968 & 47.6 & V \\
5. & Supply of quality seeds by Govt. & 32314 & 49.7 & III \\
6. $\quad$ Supply of fertilizers by govt. & 34816 & 53.6 & II \\
& $\quad$ subsidized price & & & \\
\hline Source: Computed from primary data & & &
\end{tabular}


government subsidy at higher rate with the Garrett scores of 31718 and 30968 points respectively. The last rank was assigned to direct procurement by government with the Garrett score of 29009 points. It is found from the analysis that of the expected future practices in paddy, availability of high resistance varieties and supply of fertilizers by government at subsidized price were the top most desires of the respondents.

\section{Summary of Findings}

It is stated that the mean level of the annual income remains same for all the three age groups of the paddy cultivators. It is found that majority of the male respondents have earned maximum level of annual income (205.7 thousands) than the female respondents in the study area. It is stated that the mean level of the annual income remains same for both the genders of sample farmers. It is stated that the mean level of the annual income remains same for all the five levels of education found among the sample farmers. It is found from the analysis that majority of the respondents have felt that price fluctuation and lack of storage facilities were the top most problems in paddy cultivation and the availability of high resistance varieties and supply of fertilizers by government at subsidized price are the most felt future expected practices.

\section{Conclusion}

Paddy is an important crop cultivated in Erode District, an area having no sea coast of its own. Unfortunately the productivity for the year 2014 was not accompanied by enhanced fertility due to price fluctuations. As a result it has adversely affected the farmers and their production. It is therefore, suggested that the government takes steps to improve the market potential, to supply good quality and high resistant seeds and fertilizers to the farmers at subsidized price.

\section{References}

1. Acharya, N. "Growth performance of agriculture sector", Employment News, vol. 39(11), pp. 14-20, 2014.

2. Singh, R.R., \& Srivastava, G.K. "Agricultural marketing constraints and prospects", Indian Journal of Marketing, vol. 8(8), pp. 25-29, 1978.

3. Sundaresan, R., \& Dhanasekaran, M. "Production and marketing of grapes in madurai district", Indian Journal of Marketing, vol. 14(8), pp. 26-27, 1984.

4. Ram, S. "Agricultural development in India: Problem and prospects", Kisan World, vol. 25(8), pp. 6-12, 2010.

5. Siju., \& Kombairaju. "Rice production in Tamil Nadu: A trend and decomposition analysis", Agricultural Situation in India, vol. 58(4), pp. 143-146, 2001.

6. Suresh. "Crisis in agricultural sector in Tamilnadu", Kisan World, vol. 39(11), pp. 34-38, 2012. 